\title{
BISMILLAHIRRAHMAANIRRAHIIM
}

\section{Materi Webinar IKABIO 2020 \\ Genomic surveillance: Genetic drift and environmental spreading dynamic of
COVID-19 in Indonesia}

by:

Mudyawati Kamaruddin, Ph.D

\section{Pendahuluan}

Penyakit pneumonia yang menyerang manusia disebabkan oleh tipe virus korona baru severe acute respiratory syndrome coronavirus 2 (SARS-CoV-2), yang oleh badan kesehatan dunia WHO menamakan sebagai Coronavirus Diesease-19 (COVID-19) pada tanggal 11 Februari 2020. ${ }^{1}$ Pada Desember 2019, kasus ini pertama kali dilaporkan di Wuhan, Provinsi Hubei, China, ${ }^{2}$ yaitu terdata sebanyak 5 pasien yang dirawat dengan Acute Respiratory Distress Syndrome (ARDS) antara tanggal 18 Desember hingga 29 Desember 2019, dan sejak tanggal 31 Desember 2019 hingga 3 Januari 2020 kasus ini meningkat pesat hingga mencapai 44 kasus. ${ }^{3}$ Awalnya kebanyakan laporan datang dari Hubei dan provinsi di sekitar, kemudian bertambah hingga ke provinsi-provinsi lain dan seluruh China. Belum cukup sebulan, yaitu tanggal 30 Januari 2020 COVID-19 telah menyebar di berbagai provinsi lain di China dengan 7.736 kasus terkonfirmasi, bahkan ke negara lain (Jepang, Korea Selatan, Taiwan, Vietnam, Thailand, Filipina, India, Nepal, Sri Lanka, Kamboja, Singapura, Arab Saudi, Australia, Kanada, Finlandia, Jerman dan Prancis) dengan 86 kasus ${ }^{4,5}$ Hingga tanggal 19 Juni 2020, terdapat 8.464 .739 kasus dan 453.289 jumlah kematian diseluruh dunia. ${ }^{6}$

Di Indonesia, COVID-19 pertama kali dilaporkan pada tanggal 2 Maret 2020 dengan dua kasus, ${ }^{7}$ data per 19 Juni 2020 menunjukkan kasus yang terkonfirmasi berjumlah 42.762 dan 2.339 kasus kematian, dengan rata-rata kejadian COVID-19 sebesar 15,63 per 100.000 orang. ${ }^{6}$

Peningkatan kasus COVID-19 yang semakin tinggi, mengharuskan pemerintah, lembaga kesehatan, penelitian, dan seluruh lembaga yang terkait untuk meninjau langkah yang tepat, efisiens dan efektif dalam pencegahan penyebaran COVID-19 ini. Salah satu langkah yang bisa ditempuh adalah genomic surveillance.

\section{Pentingnya Genomic Surveillance}

Genomic surveillance yang biasanya diistilahkan dalam Bahasa sebagai pengawasan terhadap genom. Jika diuraikan per kata, surveillance merupakan evaluasi klinis yang berskala pada 
individu yang berisiko lebih tinggi terkena/terpapar suatu kondisi dengan tujuan mendeteksi penyakit baru atau penyakit kambuh/berulang (recurrent). Pada kesehatan publik, surveillance juga dapat merujuk pada pengumpulan informasi yang sifatnya sistematis tentang kejadian, prevalensi, dan kematian yang terkait dengan berbagai kondisi medis atau kejadian yang berhubungan dengan kesehatan. Adapun istilah genomic dikaitkan dengan material genetik suatu organisme berupa DNA (baik DNA yang terkode dalam hal ini yang berisi gen, maupun DNA yang tidak terkode), RNA, DNA yang terdapat di nukleus (inti sel), DNA yang terdapat di mitokondria dan DNA yang terdapat di kloroplas.

Pengawasan terhadap material genetik akan menjadi suatu standar baru yang signifikan untuk tujuan analisa, kewaspadaan dan pengendalian patogen. Sebagai salah satu contoh pengawasan genomik pada konservasi dan pengolahan ternak adalah penggunaan penanda molekular diaplikasikan untuk (1) mengidentifikasi individu, spesies atau populasi; (2) mengukur perubahan metrik genetik populasi, dalam hal ini ukuran populasi yang efektif, keragaman genetik dan ukuran populasi yang berubah setiap saat; (3) mendeteksi perubahan kelimpahan dan keanekaragaman spesies.

Berdasarkan fungsi penanda molekular yang dijelaskan di atas, maka kemungkinan metode yang sama dapat diberlakukan pada virus SARS-COV-2 yang menyebabkan COVID-19. Salah satu bagian yang signifikan terkait pengawasan genomik pada kasus COVID-19, yaitu Sequence Nucleotide Variants (SNVs) yang juga dikenal dengan istilah Single Nucleotide Polymorphism (SNP atau SNIP), merupakan salah satu jenis mutasi. yaitu perbedaan dalam nukleotida tunggal (adenine, timin, guanine dan sitosin) di dalam susunan rangkaian basa DNA pada posisi atau lokasi tertentu dalam genom. Perubahan yang terjadi pada basa tunggal itu akan menyebabkan perubahan asam amino pada daerah conserve protein, yang akibatnya struktur dan fungsi ikut berubah. Ketika SNP terjadi di dalam gen atau di wilayah regulasi gen, itu akan mempengaruhi fungsi gen dengan memainkan pengaruh yang lebih besar pada penyakit. Sebagian besar SNP tidak memiliki efek pada kesehatan atau perkembangan. Namun demikian, beberapa perbedaan genetik telah terbukti sangat penting dalam studi kesehatan manusia. Para peneliti telah menemukan SNP yang dapat membantu memprediksi respons seseorang terhadap obat-obatan tertentu, kerentanan terhadap faktor lingkungan seperti racun, dan risiko mengembangkan penyakit.

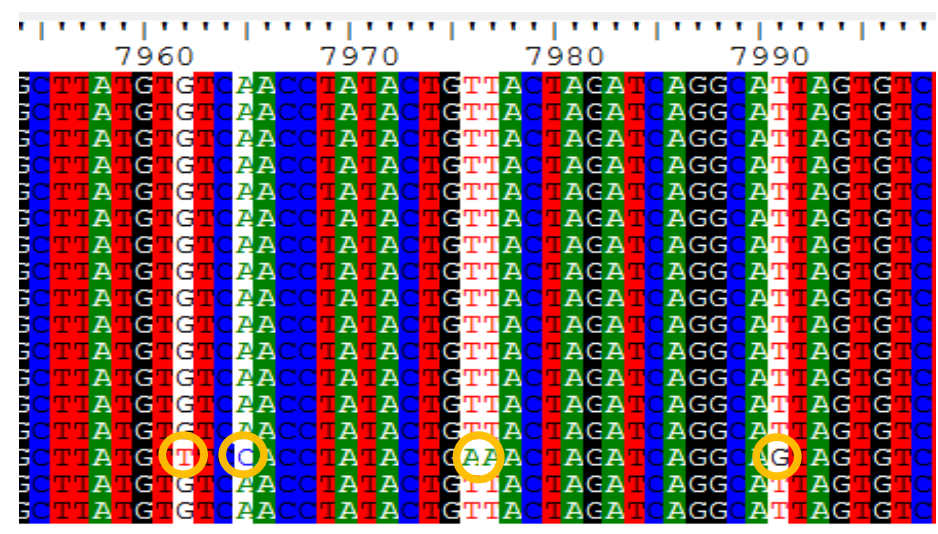

Gambar 1. SNP pada daerah ORF SARS-CoV-2 ) 


\section{SNP dan SARS-CoV-2}

Pada SARS-CoC-2, protein S dilaporkan sebagai determinan yang penting dalam masuknya virus ke dalam sel host atau pejamu (inang). Telah diketahui bahwa masuknya SARS-CoV-2 ke dalam sel dimulai dengan fusi antyara membaran virus dengan plasma membran dari sel pejamu. ${ }^{8}$ Telah diketahui Telah diketahui bahwa masuknya SARS-CoV ke dalam sel dimulai dengan fusi antara membran virus dengan plasma membran dari sel. ${ }^{9}$ Pada proses ini, protein S2 berperan penting dalam proses pembelahan proteolitik yang memediasi terjadinya proses fusi membran. Selain fusi membran, terdapat juga clathrin-dependent dan clathrin-independent endocytosis yang memediasi masuknya SARS-CoV ke dalam sel pejamu (gambar 2).

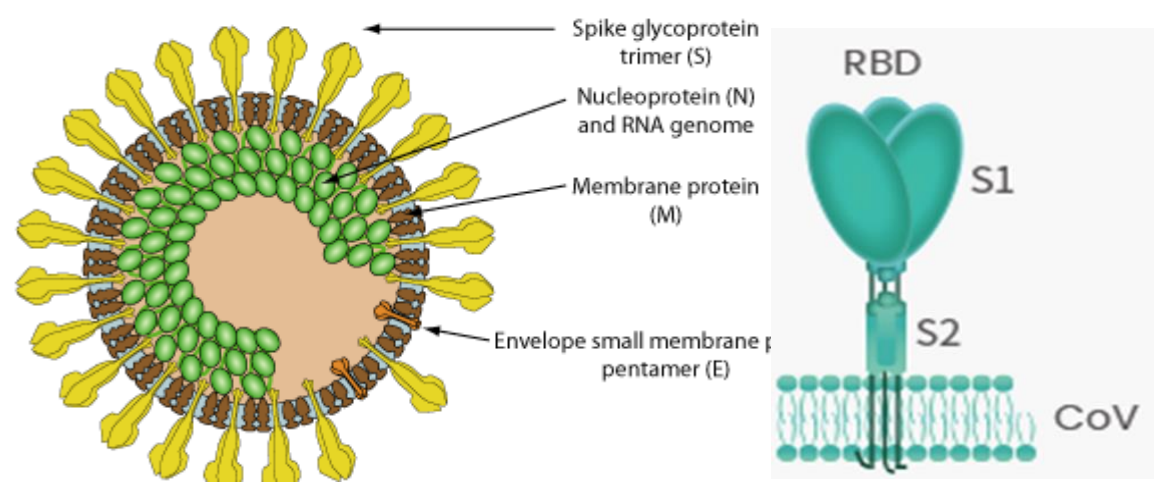

Gambar 2. Protein Spike SARS-CoV-2 RBD: Receptor-binding Domain; S1: Subunit 1; S2: Subunit 2

Faktor virus dan pejamu memiliki peran dalam infeksi SARS-CoV. Efek sitopatik virus dan kemampuannya mengalahkan respons imun menentukan keparahan infeksi. ${ }^{10}$ Disregulasi sistem imun kemudian berperan dalam kerusakan jaringan pada infeksi SARS-CoV-2. Respons imun yang tidak adekuat menyebabkan replikasi virus dan kerusakan jaringan. Di sisi lain, respons imun yang berlebihan dapat menyebabkan kerusakan jaringan. ${ }^{11}$

\section{SNP Protein S dan Pengembangan Vaksin}

Protein Spike menjadi target dalam pengembangan vaksin dan antivirus terhadap SARS-CoV2, karena di daerah protein Spike ini cenderung bermutasi. Jika mutasi terjadi lebih luas pada protein Spike khususnya pada subunit S1 dimana Receptor Binding Domain (RBD) berada, dipastikan mempengaruhi afinitas RBD terhadap reseptor Angiotensin Converting-Enzyme 2 (ACE2). Mengingat pentingnya untuk mengidentifikasi dan menganalisis SNP yang terjadi pada daerah Spike, Penting dilakukan pengidentifikasian varian pada protein Spike Virus SARS-CoV-2 yang diperoleh dari sekuens beberapa daerah di Indonesia yang disejajarkan dengan sekuens Virus SARS-CoV-2 asal Wuhan sebagai sequence comparison (gambar 3). Hasil analisis menunjukkan adanya mutation titik yang unik yaitu pada urutan asam amino Q677H protein Spike. Mutasi titik 
tersebut hanya ditemukan pada 1 pasien asal Surabaya dan juga hanya 6 negara yang mengalami mutasi di daerah tersebut (gambar 4).

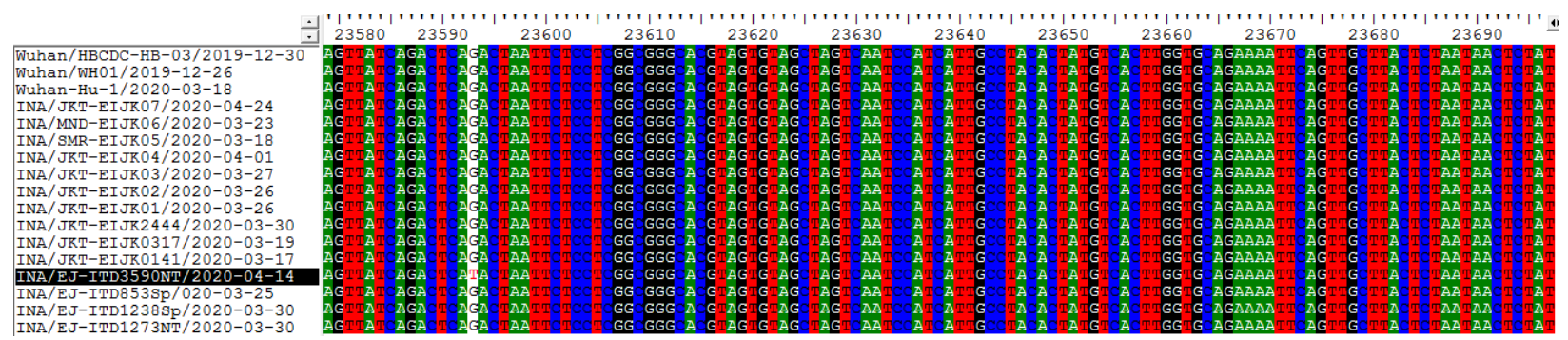

Gambar 3. SNP yang ditemukan pada sampel Indonesia pada daerah protein S yang mengubah asam amino Q677H

\begin{tabular}{|c|c|c|c|}
\hline No & Virus Name/Collecting Date & Cities & $\begin{array}{c}\text { Lineage/GISAID } \\
\text { Glade }\end{array}$ \\
\hline 1 & $\mathrm{VIC} 01 / 2020-03-21$ & Victoria (Australia) & B. 1 (S) \\
\hline 2. & UT-0291/2020-03-27 & Utah (North America) & B. $1(\mathrm{GH})$ \\
\hline 3. & Sweden $/ 20-06308 / 2020-03-20$ & Stockholm, Sweden [Europe] & B. $1(\mathrm{GH})$ \\
\hline 4. & TX-HMHO4 12/2020-03-31 & Texas (North America) & B.1.p2 (GH) \\
\hline 5. & PHWC-26F52/2020-03-28 & Wales, UK (Europe) & B. $2.1[\mathrm{~V}]$ \\
\hline 6. & NIRE-FAAOB/2020-0.4-06 & Northern Ireland, UK (Europe) & B. $10(L)$ \\
\hline 7 & GBRC21/2020-04-26 & Gujarat, India (Asia) & B. 1 (G) \\
\hline 8. & NY-NYUMC241/2020-04-0.5 & New York (North America) & B. $1(\mathrm{GH})$ \\
\hline 9. & LIVE-9F060/2020-04-15 & England, UK \{Europe\} & B. $2.2[\mathrm{~V}\}$ \\
\hline 10. & NIV-1 1687/2020-04-19 & Maharostbrg, India (Asia) & B.1.1 (GR) \\
\hline 11. & EI-ITD3590NT/2020-04-14 & Surabaya, Indonesia (Asia) & B.1.36 (GH) \\
\hline
\end{tabular}

Gambar 4. Perubahan asam amino pada daerah Q677H yang hanya ditemukan pada 6 negara

\section{Kesimpulan}

Pengawasan terhadap genom merupakan langkah yang signifikan untuk pengembangan vaksin SARS-CoV2 yang setiap strain virus menyebar berbeda di masyarakat karena terjadinya mutasi. Oleh karena itu,strategi pengembangan vaksin di Indonesia yang berdasarkan data genom dari setiap wilayah/provinsi akan menjadi pendekatan yang lebih adekuat untuk virus sejenis SARS-CoV-2 ini. 


\section{DAFTAR PUSTAKA}

1. World Health Organization. WHO Director-General's opening remarks at the media briefing on COVID-19. Available at: https://www.who.int/dg/speeches/detail/whodirector-general-opening-remarks-at-the-media-briefing-on-covid-19.

2. Rothan HA, Byrareddy SN. The epidemiology and pathogenesis of coronavirus disease (COVID-19) outbreak. J. Autoimmun. 2020; published online March 3. DOI: 10.1016/j.jaut. 2020. 102433.

3. Ren LL, Wang YM, Wu, ZQ, Xiang ZC, Guo L, Xu T, et al. Identification of a novel coronavirus causing severe Pneumonia in human: a descriptive study. Chin Med J. 2020; May 5, 2020 - Volume 133 - Issue 9 - $p$ 1015-1024. DOI: 10.1097/CM9.0000000000000722.

4. Huang C, Wang Y, Li X, Ren L, Zhao J, Hu Y, et al. Clinical features of patients infected with 2019 novel coronavirus in Wuhan, China. Lancet. 2020; 395 (10223): 497-506.

5. Adityo S, Martin R, Ceya WP, Widayat DS, Mira Y, Robert S, et al. Coronavirus disease 2019: Tinjauan literature terkini. Jurnal penyakit dalam Indonesia. 2020; 7(1): 45 -67.

6. John Hopkins University and Medicine. Coronavirus Research Center. Cited 19 June 2020. Available at: https://coronavirus.jhu.edu/map.html.

7. World Health Organization. Situation COVID-19 report-42 [Internet]. 2020 [update 2020 March 02]. Available at: https://www.who.int/docs/default-source/coronavirus/situationreports/20200302-sitrep-42-covid-19.

8. de Wit E, van Doremalen N, Falzarano D, Munster VJ. SARS and MERS: recent insights into emerging coronaviruses. Nat Rev Microbiol. 2016;14(8):523-34.

9. Simmons G, Reeves JD, Rennekamp AJ, Amberg SM, Piefer AJ, Bates P. Characterization of severe acute respiratory syndrome-associated coronavirus (SARSCoV) spike glycoprotein-mediated viral entry. Proc Natl Acad Sci U S A. 2004;101(12):4240-5.

10. Li G, Fan Y, Lai Y, Han T, Li Z, Zhou P, et al. Coronavirus infections and immune responses. J Med Virol. 2020;92(4):424-32.

11. Qin C, Zhou L, Hu Z, Zhang S, Yang S, Tao Y, et al. Dysregulation of immune response in patients with COVID-19 in Wuhan, China. Clin Infect Dis. 2020; published online March 12. DOI: $10.1093 / \mathrm{cid} / \mathrm{ciaa} 248$. 